\title{
DAMPAK PACARAN TERHADAP KONSENTRASI MAHASISWA PENS DALAM PERSPEKTIF ISLAM DAN ILMU PSIKOLOGI
}

\author{
Ray Yusra Wijaya \\ Politeknik Elektronika Negeri Surabaya \\ Kampus ITS, Jl. Raya ITS, Keputih, Kec. Sukolilo, Kota Surabaya \\ rayyusrawijaya@gmail.com \\ Abdullah Rafif \\ Politeknik Elektronika Negeri Surabaya \\ Kampus ITS, Jl. Raya ITS, Keputih, Kec. Sukolilo, Kota Surabaya \\ abdullahrafif@gmail.com \\ Muhammad Zidan Zulfikar \\ Politeknik Elektronika Negeri Surabaya \\ Kampus ITS, Jl. Raya ITS, Keputih, Kec. Sukolilo, Kota Surabaya \\ zidanzulfikar016@gmail.com \\ Imamul Arifin S, Sy. M.H. \\ Politeknik Elektronika Negeri Surabaya \\ Kampus ITS, Jl. Raya ITS, Keputih, Kec. Sukolilo, Kota Surabaya \\ imamul@pens.ac.id
}

\begin{abstract}
Abstrak
Fenomena pacaran adalah hal yang wajar bagi mahasiswa, di mana ada dua lawan jenis menghabiskan waktu bersama. Dalam prefektif psikologi pacaran sendiri dapat menimbulkan konsentrasi yang baik dan juga dapat menimbulkan konsentrasi yang buruk, bukan hanya konsentrasi yang akan terpengaruh, Kesehatan fisik, gangguan mental, dll juga akan terpengaruh. Tergantung hubungan pasangan yang di jalani. Namun pacaran ini termasuk hal yang diharamkan dalam Islam. Pada jurnal ini hal yang akan dibahas yaitu mengenai pengaruh pacaran terhadap konsentrasi mahasiswa di PENS. Metode penelitian yang digunakan dalam jurnal ini yaitu berupa metode kualitatif. Data didapatkan dengan menanyakan pendapat kepada partisipan tentang pengaruh pacaran terhadap prestasi belajar mereka. Hasil penelitian yang telah dilakukan menunjukkan bahwa pacaran memang memiliki pengaruh terhadap konsentrasi belajar mahasiswa. Mengganggu konsentrasi belajar, menurunkan prestasi kuliah, dapat memengaruhi hubungan seseorang baik dengan teman maupun keluarga, juga menyebabkan lupa hal-hal karena memikirkan pacar. Berbagai metode ada di dalam islam maupun di luar untuk meningkatkan konsentrasi belajar. Bisa dengan melakukan olahraga dan meditasi secara rutin, berdoa ketika ingin belajar, dan juga berwudhu sebelum melakukan sebuah kegiatan.
\end{abstract}

Kata kunci : pacaran, mahasiswa, pengaruh, konsentrasi. 


\begin{abstract}
The phenomenon of dating is a natural thing for students, where there are two opposite sexes spending time together. In prefective psychology, dating itself can cause good concentration and can also cause poor concentration, not only concentration will be affected, physical health, mental disorders, etc. will also be affected. It depends on the couple's relationship. However, this courtship is forbidden in Islam. In this journal, what will be discussed is the influence of courtship on the concentration of students in EEPIS. The research method used in this journal is a qualitative method. The data was obtained by asking participants' opinions about the effect of courtship on their learning achievement. The results of the research that have been carried out show that dating does have an influence on the concentration of student learning. Disrupts learning concentration, lowers college achievement, can affect one's relationships with friends and family, also causes forgetting things because of thinking about a boyfriend. Various methods exist within Islam as well as outside to increase the concentration of learning. You can do sports and meditation regularly, pray when you want to study, and also perform ablution before doing an activity.
\end{abstract}

Keywords: dating, college student, influence, concentration.

\title{
Pendahuluan
}

Pacaran memang sebuah proses yang normal, dialami oleh hampir semua orang yang ada di dunia. Apalagi paling banyak dirasakan oleh para remaja yang mulai menjadi sadar dengan lawan jenisnya. Arti kata pacar berdasarkan KBBI daring (2016) adalah teman lawan jenis yang tetap dan mempunyai hubungan berdasarkan cinta kasih yang belum terikat perkawinan. Lalu apakah itu arti pacaran ?. Pacaran secara bahasa berarti saling mengasihi atau saling mengenal. Dalam pengertian luas pacaran berarti upaya mengenal karakter seorang yang dicintai dengan cara mengadakan tatap muka (Al-Ghifari, 2014). Pacaran adalah sebuah proses perkenalan sepasang kekasih dalam rangkaian tahap pencarian menuju kehidupan berkeluarga (Nastiti, 2012). Dalam berpacaran ketika memilih pasangan yang cocok atau sesuai dapat memberikan perasaan bahagia dalam menjalani kehidupan. Kemudian, apa itu konsentrasi ?. Konsentrasi adalah proses perhatian yang melibatkan kemampuan untuk fokus pada tugas yang ada sambil mengabaikan gangguan (Moran, 2012).

Dari sinilah, muncul berbagai permasalahan, mengapa mahasiswa pacaran, apa saja pengaruh pacaran terhadap konsentrasi mahasiswa, apa yang membuat konsentrasi menjadi terganggu, kemudian terakhir yaitu apa saja cara untuk meningkatkan konsentrasi belajar. Permasalahan-permasalahan ini akan dibahas secara lanjut dalam jurnal ini.

Sebagai seseorang yang sudah beranjak ke usia dewasa, memiliki perasaan terhadap lawan jenis memang suatu hal yang normal. Perasaan-perasaan yang dimiliki tersebut bahkan dapat mengubah kepribadian seseorang dan memunculkan berbagai perasaan lain di mana perasaan tersebut bisa berupa positif maupun negatif yakni seperti rasa kecemburuan, perasaan ingin tahu terhadap lawan jenis, dan bahkan juga bisa memunculkan perasaan posesif. Selain itu, pacaran ini juga memiliki berbagai dampak yang dapat memengaruhi kedua pihak yang terlibat dalam proses pacaran ini. Beberapa 
dampak dari pacaran saat remaja ini meliputi, dapat menurunkan prestasi dalam sekolah, terjadinya sex bebas, lalu menyebabkan hamil di luar nikah dan bahkan juga dapat mengakibatkan kematian bila tidak berhati-hati. Pada jurnal ini penulis ingin membahas tentang pengaruh pacaran terhadap konsentrasi mahasiswa Teknologi Rekayasa Multimedia PENS.

Di dalam Islam kegiatan pacaran itu merupakan sesuatu yang diharamkan Allah. "Janganlah seorang laki-laki berduaan dengan seorang wanita yang tidak halal baginya karena sesungguhnya syaithan adalah orang ketiga di antara mereka berdua kecuali apabila bersama mahromnya." (H. R. Ahmad no. 15734).

"Tidak boleh antara laki-laki dan wanita berduaan kecuali disertai oleh muhrimnya, dan seorang wanita tidak boleh bepergian kecuali ditemani oleh muhramnya."(H. R. Muslim). Mengapa di dalam Islam pacaran termasuk sesuatu yang diharamkan ?.

Allah berfirman,

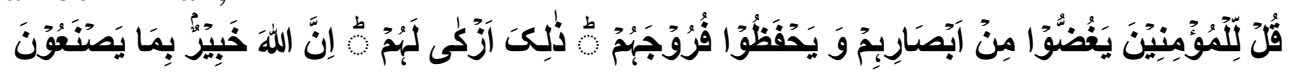

Artinya : "Katakanlah kepada orang laki-laki yang beriman: "Hendaklah mereka menahan pandangannya, dan memelihara kemaluannya; yang demikian itu adalah lebih suci bagi mereka, sesungguhnya Allah Maha Mengetahui apa yang mereka perbuat." QS. An-Nuur [24]: 30 .

Kemudian di ayat selanjutnya,

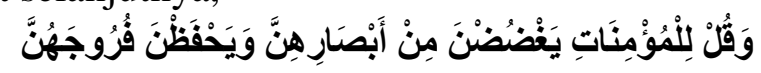

Artinya : "Katakanlah kepada wanita-wanita yang beriman : "Hendaklah mereka menundukkan pandangannya, dan kemaluannya." QS. An-Nuur [24] : 31.

Inilah alasan mengapa pacaran ini berupa kegiatan yang mendekati zina. Seperti melihat lawan jenis dengan pandangan yang tidak baik, bersentuhan dengan lawan jenis bahkan melakukan perbuatan yang hanya boleh dilakukan oleh pasangan suami-istri.

\section{Metode Penelitian}

Pada jurnal ini metode penelitian yang digunakan untuk mendapatkan data yaitu dengan metode penelitian kualitatif. Data yang didapatkan yaitu berasal dari wawancara 3 mahasiswa. Ketiga mahasiswa ini memiliki kondisi hubungan yang berbeda. Mahasiswa pertama yang tidak memiliki pacar, lalu mahasiswa kedua yang sudah putus dengan pacarnya dan sedang tidak dalam hubungan dan terakhir dengan mahasiswa ketiga yang sedang dalam hubungan dengan seorang pasangan. Penelitian ini dilakukan untuk menjelaskan tentang pengaruh kegiatan pacaran pada konsentrasi mahasiswa

\section{Hasil dan Pembahasan}

Berikut ini merupakan hasil dari wawancara tiga mahasiswa. Pertama, menurut mahasiswa yang tidak pernah pacaran pacaran hanya membuang-buang waktu dan tenaga yang harusnya dipakai untuk fokus belajar, apabila tidak pacaran maka memiliki lebih banyak waktu yang dapat dimanfaatkan untuk berbagai hal yang positif dan mempunyai kebebasan dalam berteman dan mencari relasi dikarenakan saat kita pacaran, kita akan dihadapkan dengan tembok dan dinding yang dibangun oleh pacar kita. Terutama oleh 
pacar yang posesif dan tidak ingin bergaul dengan lawan jenis, beda halnya dengan saat dengan tidak pacaran. Saat tidak pacaran, menurutnya bisa dengan bebas berteman dan membangun relasi sesuai dengan keinginannya tanpa dibatasi oleh pacar atau kekasih.

Kemudian menurut mahasiswa kedua, setelah putus dengan pacar-nya dia memiliki perasaan lega dan bebas dari tanggungan. Saat dia masih pacaran susah fokus terhadap cita-cita dan pelajaran. Ketika dia mengerjakan tugas susah fokus, juga adanya temanteman yang menyindir hubungannya dengan pacar, selain itu apabila bertengkar dengan pacar-nya dia tetap memikirkan sampai melupakan hal-hal lain. Sehingga pada saat putus dia mengatakan menjadi bebas dan bisa lebih fokus ke cita-cita sendiri.

Mahasiswa ketiga berkata pada saat wawancara bahwa salah satu pengaruh dari pacaran yaitu membuatnya terkadang lupa tugas karena sibuk memikirkan tentang pacarnya, terkadang juga akan ada waktu di mana salah satu dari mereka "galau" karena terjadi konflik di dalam hubungan pacaran yang mengakibatkan dia lupa dengan segalanya seperti terkadang lupa sholat, lupa makan, dan bahkan juga melakukan hal-hal negative seperti mabuk-mabukan untuk menghilangkan perasaan galaunya. Namun dampak positifnya, jika salah satu dari mereka mengingat tugas maka akan saling menyemangati mengerjakan tugas.

Mengapa ketika pacaran konsentrasi mudah terganggu ?. Dari wawancara yang telah dilakukan, saat pacaran penyebab terganggunya konsentrasi yaitu karena memikirkan tentang pasangan. Dalam hubungan pacaran, menghabiskan banyak waktu memikirkan tentang pasangan. Akhirnya, menyebabkan mereka pecah fokus dan sulit konsentrasi. Apalagi ketika terjadi sebuah pertengkaran atau konflik, maka akan lebih sulit fokus. Sehingga apabila seseorang dalam hubungan pacaran atau jatuh cinta, seluruh perhatiannya kemungkinan akan terpusat. Akibatnya, tingkat konsentrasi seseorang pada tugas sehariharinya, contohnya seperti belajar dan bekerja menjadi terganggu.

Walaupun dilarang dalam Islam, pacaran juga dapat memberi dampak positif. Dampak positif dari pacaran yaitu sebagai berikut. Pertama, dengan adanya pacar maka dapat saling memberi motivasi dan menyemangati sesama, juga dapat mengurangi stres, memberi rasa keamanan dan kenyamanan, selanjutnya pasangan juga bisa menjadi seseorang yang dipercaya dan mengungkapkan isi hati (Tridarmanto, 2017). Menurut Santrock (2010) hubungan pacaran memiliki beberapa peran. Pacaran dapat menjadi sebuah bentuk rekreasi, sebagai sumber status atau kesuksesan dan juga sebagai tempat untuk mempelajari hubungan dekat serta cara untuk mencari jodoh. Namun, pacaran juga datang dengan berbagai pengaruh lainnya seperti menyebabkan menurunnya prestasi belajar mahasiswa, membuat mudah hilang fokus, hamil pra-nikah juga bahkan menyebabkan kekerasan.

Menurut ilmu psikologi yang Bernama psychological well-being (kesejahteraan pskiologi) kesehatan pada fisik, dan menunjukan hamparan kehidupaan yang Lebih lama. Ketika ada sebuah pasangan yang memiliki sebuah hubungan yang baik dapat memiliki sebuah tingkat psikologis yang tinggi (Viejo, et al., 2015). Maka di simpulkan bahwa sebuah pasangan yang memiliki hubungan yang baik akan memengaruhi konsentrasi yang baik, namun jika sebuah pasangan yang tidak memiliki hubungan yang tidak baik akan memengaruhi konsentrasi yang tidak baik pula. Dengan demikian sebuah pemilihan, dan 
proses dalam sebuah pasangan harus cermat dalam menghadapi hal- hal berikut karena setiap pergerakannya akan memengaruhi psikologis orang yang menjalani hubungan.

\section{Kesimpulan}

Berdasarkan hasil penelitian dan analisis di atas, dapat diambil kesimpulan sebagai berikut. Pacaran pada masa kuliah memiliki pengaruh terhadap kehidupan mahasiswa dan mahasiswi yang terikat dalam hubungan tersebut. Salah satunya dengan memengaruhi konsentrasi atau fokus dalam pembelajaran pada masa kuliah. Cara anak muda mencegah pacaran khususnya saat menjalin pendidikan yakni selalu mengingat kepada allah SWT, ingat akan dosa - dosa yang di berikan allah SWT, rajin beribadah, jika bisa ikut dalam pengajian pengajian yang ada di lingkungan sekitar. Meski menjalin hubungan pada masa kuliah dapat memberikan sedikit dampak positif, jika tidak ditangani dengan baik maka hubungan tersebut bisa menjadi sebuah hal yang merusak kehidupan baik di lingkungan keluarga maupun pendidikan. Maka dari itu, perlunya sikap tanggung jawab dari diri sendiri sehingga kehidupan pada masa kuliah ini dapat dijalankan dengan lancar.

\section{Saran}

Terdapat berbagai cara untuk meningkatkan konsentrasi. Sebagai seorang mahasiswa, hal yang harus dipentingkan yaitu meningkatkan pengetahuan melalui belajar. Dengan meningkatkan konsentrasi ini dapat memudahkan kita untuk fokus terhadap kegiatan belajar. Tidak hanya itu, metode ini juga dapat memberi dampak positif apabila dilakukan secara rutin.

Salah satunya dengan cara meningkatkan konsentrasi yaitu dengan berolahraga, dalam studi kasus yang dilakukan oleh Dr. John Ratey (2013), menunjukkan bahwa orang yang berolahraga dengan waktu sekitar 30 menit dapat meningkatkan kemampuan seseorang untuk fokus dan konsentrasi dibandingkan dengan orang yang tidak. Olahraga juga memiliki dampak positif lainnya, dengan berolahraga kita juga dapat membuat tubuh lebih sehat dan mengurangi risiko terkena penyakit.

Metode selanjutnya yaitu dengan bermeditasi, menurut riset yang dipublikasikan dalam jurnal Psychological Science menunjukkan bahwa kegiatan meditasi dapat meningkatkan fokus dan mempertahankan perhatian mereka (MacLean dkk., 2010). Meditasi dapat dilakukan sebelum belajar sehingga dapat fokus terhadap materi yang akan dipelajari. Meditasi dengan waktu yang cukup dapat menenangkan pikiran, meningkatkan suasana hati dan juga mengurangi stres.

Kemudian untuk meningkatkan konsentrasi juga dapat dengan cara berwudhu sebelum belajar. Dari riset yang telah dilakukan menunjukkan bahwa wudhu sebelum sebelum belajar memang memiliki pengaruh positif terhadap konsentrasi dan fokus seseorang (Hidayati dan Zarkasyi, 2021). Selain itu, berwudhu secara rutin sebelum tidur juga dapat memperbaiki kualitas tidur (Lestari dan Minan, 2018). Kualitas tidur juga berpengaruh terhadap kinerja kognitif. Kurangnya waktu tidur yang cukup dapat memengaruhi perhatian dan ingatan. Fungsi lainnya seperti memori jangka panjang dan kemampuan pengambilan keputusan juga dapat terpengaruh (Alhola dan Polo-Kantola, 
2007). Maka dari itu, dianjurkan untuk mahasiswa waktu tidur yang cukup yaitu sekitar 7 jam lebih. Dan jangan lupa juga sebelum memulai belajar membaca doa.

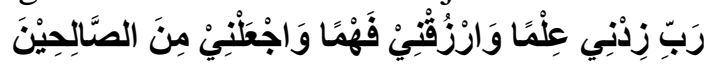

Artinya : "Ya Tuhanku, tambahkanlah ilmu kepadaku, dan berikan aku karunia untuk memahaminya, dan jadikanlah aku termasuk golongan orang-orang yang saleh.”

\section{DAFTAR PUSTAKA}

Al-Ghifari, A (2004). Gelombang kejahatan seks remaja modern. Bandung: Mujahid BUCIN ITU BUKAN CINTA. widya cakra : Journal of Psychology and Humanities.

KBBI Daring. (2016). Retrieved October 26, 2021, from https://kbbi.kemdikbud.go.id/entri/pacar.

Moran, A. (2012). Concentration: Attention and Performance. In S. M. Murphy (Ed.), The Oxford Handbook of Sport and Performance Psychology (p. 117). essay, Oxford University Press.

Nastiti, T. (2012). (dissertation). Layanan Konseling Kelompok Behavioral untuk Mengubah Perilaku Pacaran Siswa Kelas IX SMP N 2 Suruh. Retrieved December 4, 2012, from https://repository.uksw.edu/handle/123456789/1692

Tridarmanto, Y. K. (2017). KONSEP DAN KEBUTUHAN BERPACARAN REMAJA AWAL DI YOGYAKARTA. Skripsi. Sanata Dharma University

Santrock, J. W. (2011). Life-span development (13th ed., p. 394). New York: McGraw-Hill

Sorenson, S. (2007). Adolescence Romantic Relationships. Retrieved October 23, 2021, from http://www.actforyouth.net/resources/rf/rf_romantic_0707.cfm

Ratey, J., \& Hagerman, E. (2013). Spark: The revolutionary new science of exercise and the brain. Little, Brown.

MacLean, K. A., Ferrer, E., Aichele, S. R., Bridwell, D. A., Zanesco, A. P., Jacobs, T. L., King, B. $\quad$ G., Rosenberg, E. L., Sahdra, B. K., Shaver, P. R., Wallace, B. A., Mangun, G. R., \& Saron, C. D. (2010). Intensive Meditation Training Improves Perceptual Discrimination and Sustained Attention. Psychological Science, 21(6), 829-839. https://doi.org/10.1177/0956797610371339

Hidayati, E., \& Zarkasyi, F. A. (2021). PENGARUH WUDHU TERHADAP PENINGKATAN KONSENTRASI BELAJAR REMAJA. Jurnal Keperawatan Dan Kesehatan Masyarakat Cendekia Utama, 10(2), 108-114. https://doi.org/10.31596/jcu.v10i2.756

Dwi Lestari, N., \& Rofiqul Minan, M. (2018). Efektivitas Terapi wudhu Menjelang Tidur TERHADAP Kualitas Tidur Remaja. Mutiara Medika: Jurnal Kedokteran Dan Kesehatan, $\quad$ 18(2). https://doi.org/10.18196/mm.180215

Alhola, P., \& Polo-Kantola, P. (2007). Sleep deprivation: Impact on cognitive performance. Neuropsychiatric disease and treatment, 3(5), 553-567. 